\title{
MARKET DRIVING BEHAVIOUR IN ORGANISATIONS: ANTECEDENTS AND OUTCOMES
}

\author{
Jurie van Vuuren and Nadin Wörgötter \\ Department of Business Management, University of Pretoria
}

Accepted: March 2013

\begin{abstract}
Previous research suggests that the market driving behaviour of firms is linked to exceptional performance. However, the elements of market driving, its antecedents and outcomes, have so far not been empirically measured. The primary objectives of this study are to identify factors that describe market driving, develop a conceptual model, and then consider influencing factors and performance indicators drawn from the entrepreneurship and marketing literature. The model has been empirically tested using a sample of managers in the South African healthcare industry. A fully structured questionnaire was used to address the objective of this study. The realised sample of $n=328$ was used to analyse the conceptual model applying a partial least squares path modelling approach (PLS-PM). The results revealed that market driving is a firm behaviour and is distinguished by three distinct concepts: market sensing, influencing customer preferences and alliance formation. Three out of four antecedents: strategic orientation, entrepreneurial capital and entrepreneurial behaviour, influenced market driving ability positively. The study also demonstrated that market driving behaviour positively influences firm performance and relative competitive strength.
\end{abstract}

Key words: corporate entrepreneurship, entrepreneurial marketing, market driving, firm performance, competitive strength

JEL: L200, 210, 220, 260

1

\section{Introduction}

Two major organisational objectives are to achieve firm performance and a competitive advantage; strategies to achieve these objectives differ widely across the fields of entrepreneurship and marketing. Whereas research in the field of corporate entrepreneurship outlines factors that facilitate innovation, which is considered to be the primary driver for firm performance and competitive advantage (Antoncic \& Hisrich, 2001; Covin \& Slevin, 1991; Covin \& Miles, 1999; Hisrich \& Peters, 1986; Holt, Rutherford \& Clohessy, 2007; Hornsby, Naffziger, Kuratko \& Montagno, 1993; Hornsby, Kuratko \& Montagno, 1999; Hornsby, Kuratko \& Zahra, 2002; Ireland, Hitt \& Vaidyanath, 2002; Khandwalla, 1987; Kuratko, Montagno \& Hornsby, 1990; Kuratko, Hornsby, Naffziger \& Montagno, 1993; Kuratko, Ireland \& Hornsby, 2001; Dess, Ireland, Zahra, Floyd, Janney \& Lane, 2003; Zahra, 1991) research in the field of market orientation considers the implementation of the marketing concept to be the crucial factor in achieving these outcomes (Jaworski \& Kohli, 1993; Kohli \& Jaworski, 1990:1-3; Kirca, Jayachandran \& Bearden, 2005).

Entrepreneurial marketing research has addressed the interface of marketing and entrepreneurship and considers core elements of both disciplines in order to understand firm specific outcomes parameters. Carson (2010:8) summarises the commonalities and states that both disciplines consider innovation, creativity, opportunistic behaviour, flexibility and change orientation. Both disciplines include managerial perspective and organisational behaviour. Moreover, both disciplines are process-based and market-driven.

However, as outlined by Kumar, Scheer and Kotler (2000) and Schindehutte, Morris and Kocak (2008), contemporary research at the interface is concerned with an understanding of exceptional firm performance and competitive advantage, which cannot be explained by a market driven understanding of the firm (Kumar et al., 2000; Schindehutte et al., 2008). 
To date, little research has been conducted on market driving, the characteristics of the concept, the influencing factors and the outcomes. Previous research in the field is based on secondary research (Jaworski, Kohli \& Sahay, 2000; Kumar et al., 2000) or singlecase studies (Harris \& Cai, 2002), leaving a gap in research and understanding of the concept. Numerous researchers highlight the need to develop an approach to measuring market driving behaviour (Barlow Hills \& Sarin, 2003:21; Carrillat, Jaramillo \& Locander, 2004:10; Jaworski et al., 2000:53), the need to identify which organisational factors facilitate or hinder the firm in becoming market driving and identify and measure market driving outcomes, e.g. performance, competitive advantage (Barlow Hills \& Sarin, 2003:21; Schindehutte et al., 2008:22).

Market driving research has so far not resulted in an empirical assessment of the concept itself or of quantitative measurement of antecedents and outcomes. Thus, the goal of this research is to develop a conceptual model of market driving ability and to quantitatively assess firm internal factors that influence market driving ability and determine the outcomes of market driving behaviour on firm performance and competitive advantage in the South African healthcare industry.

The South African healthcare industry is fragmented, with many players in the different sectors, such as manufacturers of pharmaceuticals and devices, distributors, wholesalers and medical schemes. Various regulatory changes in the past, like the introduction of single-exit price for pharmaceutical manufacturers, as well as future challenges, like the implementation of the National Health Insurance system, require market players to re-visit their current market positions and adapt their offerings to the evolving environment. The dynamics in the healthcare industry, the growth potential and the regulatory challenges make it an ideal industry for studying the market driving ability of organisations.

The primary objective of this study is to develop a conceptual model that will help determine how market driving can be assessed in organisations, as well as which firm internal factors will influence an organisation's ability to become market driving and determine whether market driving behaviour will influence a firms' performance and competitive advantage. The conceptual model will be subject to empirical testing.

\section{2}

\section{Background / Literature review}

Kumar et al. (2000:131-132) describe market driving as a firm orientation that is distinct from other orientations like customer, sales or market driven orientation. A market driving organisation seeks to change the industry segmentation, channel reconfiguration, provide customer education and exceed customers' expectations. The outcome for an organisation is to create a sustainable competitive advantage and superior firm performance (Schindehutte et al., 2008:5). Kim and Mauborgne (2005: $22,25)$ reflect the view that organisations need to enter new market spaces and create the demand among customers to achieve sustainable value for the organisation.

Market driving is often performed by new entrants to a market. Existing larger organisations can also become market driving, but they need to enforce an entrepreneurial mindset towards more risk-taking and innovation (Kumar et al., 2000:135). Schindehutte et al. (2008:13) concur and argue that organisations that want to shape, change or create markets need to consider various strategic orientations such as an entrepreneurial orientation, a market orientation and a technological orientation to trigger innovation in order to achieve superior performance. Kim and Mauborgne (2005:22) also state that when tapping into new markets, organisations need a different approach. However, they argue that the approach is not to increase risk-taking but rather to show how to minimise risk by appropriating strategic planning and execution.

\section{Elements of market driving}

In previous research, market driving has been observed as a unique set of abilities required to influence the market or the behaviour of stakeholders to enhance the business performance of a business (Jaworski et al., 2000:45). The question that arises is: What constitutes market driving and how can firms influence or change the behaviour of an entire market or its 
stakeholders? Harris and Cai (2002:185) present a single-case study of De Beers entering the Chinese market. The constructs that have been observed to contribute to the success of an organisation entering an entirely new market are market sensing, changing customer preferences, alliance formation and local sensitivity. Other researchers in the field (Jaworski et al., 2000:47; Kumar et al., 2000) have described similar perspectives, such as providing unique business systems by utilising forward-sensing activities and actioning to actively change the market and its stakeholders. Considering the various dimensions that can characterise market driving, the construct will be considered as multidimensional.

In view of the limited but consistent research in the field of market driving, the main descriptors of the construct to be considered, namely market sensing, influencing customer preferences and alliance formation, will be discussed in more detail.

Market sensing has been described as the process of information gathering to learn about the market and future events in order to increase opportunity for recognition and changing the market (Barringer \& Bluedorn, 1999:423; Harris \& Cai, 2002:185). Jaworski et al. (2000:51), in concurrence with Miller and Friesen (1982:12), also highlight the need for understanding the unmet needs in the market. It is necessary to specifically identify latent needs which are not obvious in the existing or new market in order to understand buying patterns and to shape the market. Narver, Slater and MacLachlan (2004:335) provide a similar view and describe a proactive market orientation to be reflected in uncovering a customer's latent needs and trying to satisfy them. Harris and Cai $(2002: 185)$ report that market sensing in the form of generating and using information to change the market is considered to be an important aspect of market driving. Very little of the research outlined above has measured market sensing empirically. Barringer and Bluedorn (1999:423), who extend the measures developed by Miller and Friesen (1982), provide the scanning intensity measure. The scale measures the extent and comprehensiveness of efforts made in scanning the environment to identify trends and opportunities. The 12-item scale demonstrates acceptable reliability (Cronbach's alpha $=0.83$ ). Discriminant validity was established by exploratory factor analysis. Two modified items from Miller and Friesen's (1982) measures did not load high on any factor. Overall the study finds that a firm's scanning intensity is vital to recognising opportunities (Barringer \& Bluedorn, 1999:436). Based on the literature review it is hypothesised that; $\mathrm{H}_{\mathrm{A}} 1$ : Market driving can be measured by market sensing activities.

Another element outlined frequently in the market driving literature has been described as changing or influencing customer preferences. Kumar et al. (2000:134-135) state that market driving firms can exceed customers' expectations by providing services that are not provided by competitors for the same price. If firms create a radical new concept, the primary focus should be on educating customers about the existence of the product and communicating how to use it. Jaworski et al. (2000:51-52) echo the view that influencing customers' behaviour is an essential part of market driving behaviour. By drawing customers' attention to details or attributes that have not been noticed before, the firm can shape customers' behaviour (Jaworski et al., 2000:47). Narver et al. (2004:336) suggest that by monitoring complaints or obtaining market information the firm could identify different ways in which customers use the product and then develop it further to tap into new markets. Previous research conducted in the field of market driving has not measured empirically the construct of influencing customer behaviour. However, Narver et al. (2004:336) developed a scale called MOPRO (proactive market orientation), which consists of items that capture customers' latent needs by monitoring customer behaviour and exceeding customer expectations. Furthermore, a proactive market orientation involves leading the customer. The refined MOPRO scale consisted of eight items and demonstrates acceptable reliability (Cronbach's alpha $=0.892)$. Unidimensionality was assessed in confirmatory factor analysis. The hypothesis derived from the discussions above is: $\mathrm{H}_{\mathrm{A}} 2$ : Market driving can be measured by activities related to influencing customer preferences. Market sensing was measured by five items which were adapted 
from the scanning intensity scale by Barringer and Bluedorn (1999) and the scanning items used by Miller and Friesen (1982). A summary of items is provided in Annexure A.

When firms seek to enter new markets, building strategic alliances with other stakeholders is an option (Harris \& Cai, 2000:187). Alliances have been shown to positively influence new product development as well as identify new opportunities (Baron \& Markman, 2000:111; Deeds \& Hill, 1996:41; Gulati, 1999:399). In addition, they can help to obtain resources and capabilities from external sources (Teng \& Cummings, 2002:86). However, several factors influence the likelihood and success of strategic alliances. In previous research it was found that the likelihood of entering into new alliances is influenced by the number of network resources. Network resources are described as the extent of information that is available to the firm owing to its position within networks. The number of new alliances that are entered into depends on past experience with alliances, and on whether high levels of trust and cooperation have been established. It also depends on the type of capabilities a firm can acquire by entering the alliance (Baron \& Markman, 2000:111; Gulati 1999:405,413; Ireland et al., 2002:413).

The use of strategic alliances is most often operationalized as an independent variable indicating a specific number of alliances and the duration of the alliance in the areas of research and development, marketing, licensing agreements or cross-licensing (Deeds \& Hill, 1996:48; Dickson \& Weaver, 1997:411; Gulati, 1999:405; Hitt, Dacin, Levitas, Arregle \& Borza, 2000:457; Kale, Singh \& Perlmutter, 2000:226).

Rothaermel and Deeds (2006:441-442) consider in their measure to be the management aspect of alliances. Their measure considers alliance type through the number of research and development alliances the firm has entered into. Alliance experience; the firm's alliance duration; and alliance management capability were measured by the number of alliances a firm was able to manage productively. Discriminant validity for alliance management capability was established (Rothaermel \& Deeds, 2006:445).

Whereas Rothaermel and Deeds (2006) focus on the management of alliances, Kale et al. (2000:220) research the concept of the trust that must be present in alliances. Kale et al. (2000) measured the aspects of trust which develops between firms based on close interaction at a personal level by means of the construct "relational capital". A five-item measure was used to capture mutual trust between alliance partners (Kale et al., 2000: 237). Reliability was assessed, using Cronbach's alpha, which was very satisfactory (alpha $=0.906)$. Content validity was established by pre-testing the survey instrument (Kale et al., 2000:226). Considering the current literature on alliance formation the following hypothesis is put forward: $\mathrm{H}_{\mathrm{A}} 3$ : Market driving can be measured by alliance formation activities. The construct was measured by five self-constructed items for which ideas were taken from Kale et al. (2000), Baron and Markman (2000) and Gulati (1999).

The review of the literature suggests that the construct of market driving has multiple facets that target shaping or changing the behaviour of stakeholders, the market or the industry with the goal to achieve a competitive advantage and firm performance. Previous research emphasises the need to develop a measure for market driving, identify factors that influence the capability to become market driving and measure outcomes of market driving behaviour (Barlow Hills \& Sarin, 2003:21; Carrillat et al., 2004:10; Jaworski et al., 2000:53; Schindehutte et al., 2008:22).

In the following section, a conceptual model of market driving ability is developed. It has been argued that an organisation's ability to become market driving is influenced by, inter alia, a firm's competencies (Schindehutte et al., 2008:13). The purpose of the conceptual model is to determine which competencies at a firm internal level will positively influence market driving ability; and to outline the relationship between market driving ability and firm level outcomes such as competitive advantage and firm performance. The conceptual model is then transferred into a measurement model.

\section{3}

\section{Conceptual model of market driving ability: Antecedents and outcomes}

In the literature, competencies are described as building blocks of firm performance, 
representing bundles of skills and resources. To achieve firm performance, competencies must have value in the market (Harmsen \& Jensen, 2004:533,535). Because market driving has been described as a firm behaviour that creates value by engaging in innovative activities (Barlow Hills \& Sarin, 2003:15; Kumar et al., 2000), firm internal factors have to be determined that contribute to achieving market driving ability and ultimately a relative competitive advantage and firm performance.

The following figure presents the conceptual model of market driving ability and its elements, which will be discussed in the following paragraphs. The conceptual model is influenced by suggestions of contemporary market driving research (Barlow Hills \& Sarin, 2003; Carrillat et al., 2004; Harris \& Cai, 2002; Kumar et al., 2000). The integrative model by Schindehutte et al. (2008) can be considered the most advanced model to assess market driving, so it is the primary basis for this study. It is understood that certain other concepts and strategic orientations investigated in contemporary corporate entrepreneurship and market orientation research, such as external environmental factors (Guth \& Ginsberg, 1990) or the technology orientation (Schindehutte et al., 2008), might have to be included in this model. However, the number of concepts had to be limited to provide empirical evidence for the hypotheses.

\section{Figure 1}

Conceptual model of market driving ability in corporate entrepreneurship

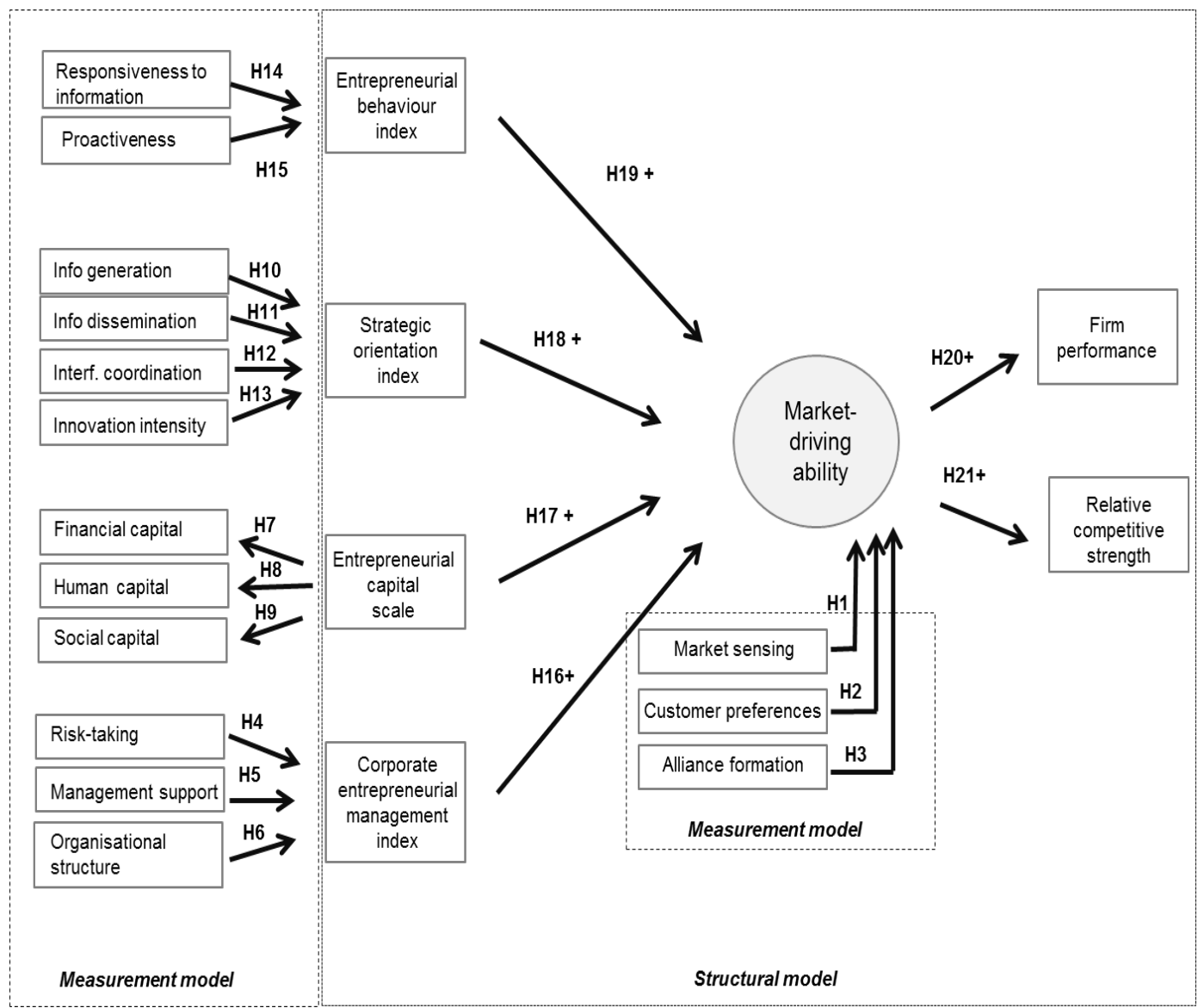

Source: Author's own compilation 
The entrepreneurship and marketing literature have significant stakes in market driving research. Both disciplines outline concepts which facilitate an organisation's market and entrepreneurial orientation. Schindehutte et al. (2008:13) suggest that antecedents to market driving derive from various strategic orientations such as a market orientation, an entrepreneurial orientation as well as firm specific factors. However, Schindehutte et al. (2008) have not tested their model empirically. The following paragraphs therefore present a review of firm internal influencing factors as well as outcomes and how they have been used in previous research studies.

The proposed conceptual model suggests that four firm internal factors impact the market driving ability of organisations, namely corporate entrepreneurial management, entrepreneurial capital, strategic orientation and entrepreneurial behaviour. These four dimensions are considered to be multidimensional constructs, whereby corporate entrepreneurial management, strategic orientation and entrepreneurial behaviour are considered to be second-order formative constructs for which an index will be developed. For entrepreneurial capital, a scale will be developed that considers the construct as second-order reflective. Multidimensional constructs are often used in research to assess an overall latent variable that cannot be observed directly (Diamantopoulos, Riefler \& Roth, 2008:1205; Edwards, 2001:144; Law, Wong \& Mobley, 1998:741; Law \& Wong, 1999:144; MacKenzie, Podsakoff \& Burke Jarvis, 2005:711). It is, however, important to clearly define the relationships between the construct and its dimensions, as each dimension and its observed variables can be specified in a reflective or formative way (Diamantopoulos et al., 2008:1205-1206). A reflective perspective considers the construct to cause the measures, whereas a formative perspective considers the indicators to cause the latent construct (MacKenzie et al., 2005:710). Whichever perspective is applied must be assessed by considering four aspects of causality, intercorrelation, error term, antecedents and consequences (Bollen \& Lennox, 1991:306; Burke Jarvis, MacKenzie \& Podsakoff, 2003: 203; Diamantopoulos et al., 2008:1205; Law \& Wong, 1999:144-145; MacCallum \& Browne,
1993:533; MacKenzie et al., 2005:711,713).

Several studies (e.g. Burke Jarvis et al., 2003:208; George, 2011:12-15; Cadogan, Souchon \& Procter, 2008:1263; Kreiser, Marino \& Weaver, 2002:85-86) have assessed entrepreneurial and market oriented constructs and their specification of constructs and dimensions in a reflective or formative way. Kreiser et al., (2002:86) conclude their assessment with the advice that the research objective in terms of accuracy versus simplicity should be guiding the decision as to which view should be applied. If simplicity is more important, a combined measurement in the form of a reflective specification is appropriate. As the field of market driving is still in early stages when it comes to the empirical measurement of key constructs, this research is concerned with the appropriate definition and measurement of these constructs. Rossiter (2002:306-308) provides a six-stage process of scale development. By following the outlined steps, the research will come to a conclusion as to which perspective should be applied. Rossiter's (2002) scale development process was consequently applied in this study.

A statistical modelling approach is applied in this study. The framework considers cause and effect relationships between constructs, while structural equation modelling (SEM) is used to quantitatively assess cause-effect relationships between variables of interest (Jaccard \& Jacoby, 2010:137-138; Pearl, 2007:135; Shmueli, 2010:289). SEM consists of a measurement model that specifies the relationships between the latent variables and their measures and a structural model that specifies the relationships between the latent variables (Diamantopoulos et al., 2008:1204). The following sections will outline the hypotheses for both parts.

\section{Corporate entrepreneurial management}

As shown previously, in order to achieve market driving ability in larger organisations, several firm internal hurdles have to be addressed (Kumar et al., 2000:136). Schindehutte et al. (2008:22) also point out that, although there might be several triggers to move into new strategic directions, corporate variables might hinder a progression.

Previous research in the field of corporate 
entrepreneurship outlined the importance of organisational factors that have to be in place to create an environment that is conducive to fostering entrepreneurial behaviour amongst associates and to intensifying their commitment (Hornsby et al., 2002:261; Kuratko et al., 1993:30; Zahra, 1991:267). Management support has been described by encouraging and supporting associates with new ideas in various ways. Providing the required resources, such as time and money, as well as recognising people who develop new ideas, fosters corporate entrepreneurship (Hornsby et al., 1993:32; Hornsby et al., 2002:259). Antoncic and Hisrich (2001:519) found that management support significantly and positively influences entrepreneurial behaviour in organisations.

Brown, Davidsson \& Wiklund (2001:964) also emphasise management's responsibility to be a facilitator in entrepreneurial initiatives. Encouraging risk-taking behaviour and tolerance for failure as well as providing an organisational structure that gives associates the flexibility to work outside their formal job specifications and structures and using informal networks have also been shown to influence corporate entrepreneurship (Brown et al., 2001: 956; Covin \& Slevin, 1991:17; Hornsby et al., 2002:260). Green, Covin \& Slevin (2008:369) conclude in their study that an organic organisational structure with open communication channels and loose and informal control mechanisms strengthens a firm's ability to respond to opportunities.

Reviewing the literature on market orientation provides a very similar view when it comes to the organisational prerequisites. Jaworski and Kohli (1993:63) found that top management's continuous emphasis on tracking market developments influences the market orientation behaviour of associates. Furthermore, if management is less inclined to take risks, the organisation's ability to respond to customer preferences is diminished. Kirca et al. (2005: 29) concur with these views, finding in a metaanalysis that top management emphasis is an important antecedent of market orientation. Support for the importance of management involvement in corporate entrepreneurship is also provided by Atuahene-Gima and Ko (2001:61, 68).

Regarding an organisational structure that is conducive to market orientation behaviour, Jaworski and Kohli (1993:63) found that centralisation of decision-making, hence not giving associates the authority to act autonomously within set boundaries, is a barrier to market orientation. On the other hand, open communication channels and connectedness among departments increases a market orientation. Kirca et al. (2005:29) as well as Matsuno, Mentzer \& Özsomer (2002:25) could not find that centralisation is negatively related to market orientation. However, departmentalisation, in form of sheer number of departments in an organisation, did have a significant negative impact on market orientation (Matsuno et al., 2002:25).

The literature review suggests that management is a key driver in an organisation's endeavour to increase its market driving ability. Support for this hypothesis is found in the study by Kumar et al. (2000:135,136), who state that market driving requires the organisation's leaders to be open to taking risks, considering that the process of generating new ideas entails a certain degree of serendipity.

If management in general provides support for entrepreneurial activities, encourages risktaking and aligns the organisational structure to facilitate entrepreneurship, it will be tested with the following alternative hypotheses.

$\mathrm{H}_{\mathrm{A}} 4$ : Corporate entrepreneurial management can be measured by risk-taking activities;

$\mathrm{H}_{\mathrm{A}}$ 5: Corporate entrepreneurial management can be measured by management support;

$\mathrm{H}_{\mathrm{A}}$ 6: Corporate entrepreneurial management can be measured by organisational structure;

Whether corporate entrepreneurial management will positively influence an organisation's market driving ability will be tested by the following alternative hypothesis in the structural model.

$\mathrm{H}_{\mathrm{A}}$ 16: Corporate entrepreneurial management positively influences market driving ability.

Risk-taking was measured by the two items developed by Miller and Friesen (1982), which have been used in numerous previous studies (Kreiser et al., 2002; Miles \& Arnold, 1991; Morris \& Sexton, 1996; Smart \& Conant, 1994). Management support consisted of four items which were derived from Hornsby et al. (2002). Organisational structure also consisted 
of four items, adapted from Hornsby et al. (2002) and from Khandwalla's study (1977).

\section{Entrepreneurial capital}

The literature on market driving consistently states that organisations need to have certain superior competencies to be able to shape, change or create the market (Carrillat et al., 2004:1527; Barlow Hills \& Sarin, 2001:219; Schindehutte et al., 2008:11,12).

Considering internal capabilities as a prerequisite for achieving competitive advantage is also investigated under the resource-based view of organisations (Barney, 1991:100). The resource-advantage theory suggests that, by managing existing resources in the form of entrepreneurial skills and capabilities, or obtaining new resources, firms can achieve a competitive advantage (Hunt \& Morgan, 1996: 109).

Tangible and intangible resources have been considered in previous research and are considered to influence an organisation's performance and competitive advantage (Miller \& Friesen, 1982:4, Schindehutte et al., 2008:11). Tangible resources include buildings and financial capital. Intangible resources refer to human and social capital (Hitt et al., 2001:13; Hitt \& Ireland, 2002:3). It has been argued that intangible resources are difficult to imitate and hence provide a source of competitive advantage (Hitt et al., 2001:13; Hitt \& Ireland, 2002:4; Rauch, Frese \& Utsch, 2005:683).

Human capital, which includes attributes such as education, experience and skills, is considered to be a critical factor in achieving firm success (Hitt et al., 2001:14; Hitt \& Ireland, 2002:4; Rauch et al., 2005:682). Individuals' social capital can be described as their ability to obtain necessary resources, such as information, and receive increased trust and cooperation from others (Baron \& Markman, 2000:107; De Carolis, Litzki \& Eddleston, 2009:529).

In a meta-analysis, Unger, Rauch, Frese and Rosenbusch (2011) found that human capital positively influences a firm's success and hence its financial capital. A similar relationship is reported by Brush, Greene \& Hart (2001:71), who found that human capital can be used to leverage social contacts who can help to secure cooperation and financial capital.
In the literature presented above, the importance of various resources to achieve market driving is evident. The outlined interdependence of the three facets, financial, social and human capital, makes it necessary to apply a reflective specification of the construct. Therefore the following alternative hypotheses derive:

$\mathrm{H}_{\mathrm{A}}$ 7: Entrepreneurial capital is reflected in financial capital;

$\mathrm{H}_{\mathrm{A}}$ 8: Entrepreneurial capital is reflected in human capital;

$\mathrm{H}_{\mathrm{A}}$ 9: Entrepreneurial capital is reflected in social capital.

In the structural model it is hypothesised that:

$\mathrm{H}_{\mathrm{A}} 17$ : Entrepreneurial capital positively influences market driving ability.

Financial capital was measured by three items. The items were self-constructed; ideas were taken from Miller and Friesen (1982) and Khandwalla (1977). Human capital included three items which were self-constructed; ideas were taken from Unger et al. (2011) and Rauch et al. (2005). Social capital also considered three items which were self-constructed; ideas for the item development were taken from Baron and Markman (2000).

\section{Strategic orientation}

In general a business strategy describes how a firm decides to compete in an industry and how certain performance outcomes will be achieved. The strategic orientation of a firm relates to the way in which a firm tries to achieve these outcomes (Morgan \& Strong, 2003:164-165).

Kumar et al. (2000:130) point out that market driving firms create a leap in customer value based on radical innovation, by introducing a new technology or value proposition. Schindehutte et al. (2008:21) concur with the view that innovation is a central part for becoming market driving and achieving competitive advantage.

In entrepreneurship research the concept of innovation is often researched together with the concepts of proactiveness and risk-taking, building a unidimensional construct of entrepreneurship (Miller, 1983:779; Rauch et al., 2009:2-3). However, Lumpkin and Dess (1996:150) suggest that the dimensions of the 
entrepreneurship construct are distinct and can vary independently of each other. Moreover, Chadwick, Barnett \& Dwyer (2008:77) find support that innovation is a distinct factor that can be modelled individually.

Besides the discussion around the dimensionality of the entrepreneurship construct, researchers have also investigated the intensity of entrepreneurship, characterised by the degree and the amount of entrepreneurship needed to impact performance (Morris \& Sexton, 1996:5,10). It was found that the degree of entrepreneurial events, such as developing new products and services, has a higher weighting than the amount or the frequency of new developments (Morris \& Sexton, 1996:7). Dess et al. (1999:97) provide a similar view and argue that entrepreneurship must be considered from a temporal perspective, meaning that an organisation can demonstrate different levels of the entrepreneurial dimension depending on the situation the business finds itself in.

In line with the arguments presented above, the concept of innovation intensity, which considers a firm's general predisposition towards innovation in terms of the number and significance of innovations, is considered as an element of the strategic dimension.

According to Schindehutte et al. (2008:17), organisations cannot constantly be market driving, but there should be transition into phases of market driven patterns, whereby they respond to customer or market needs and improve existing offerings. However, at a stage when there is increased competition, market driving firms re-start the innovation process to maintain their competitive advantage. This view is also reflected by other researchers (Harris \& Cai, 2002:184; Jaworski et al., 2000:47) who find that a market driven approach is necessary for a market driving organisation.

A market driven approach refers to an organisation's reaction to expressed customer needs. In the market driven business orientation, the customer is at the centre of all activities, which influences the way in which the organisation approaches its customers, employees and competitors (Day, 1998:8-10; Narver et al., 2004:336; Slater \& Narver, 1998:1001-1003; Tuominen, Rajala \& Möller,
2004:208). Previous researchers have described market driven approaches interchangeably with a market orientation of the organisation (Jaworski et al., 2000:45,47).

Research conducted by Kohli and Jaworski (1990), Jaworski and Kohli (1993), Kohli et al. (1993) and Narver and Slater (1990) form the basis of the market orientation construct. Kohli and Jaworski (1990:1-3; 1993:468) conceptualise market orientation as consisting of organisationwide information generation, dissemination and responsiveness to information. Information generation refers to monitoring and collecting information about the external environment, customers and competitors. Information dissemination represents the communication process that has to take place to distribute the information among relevant departments in the organisation. The third dimension, responsiveness to the information, represents the actions that have to be taken (Diamantopoulos \& Hart, 1993:96).

Narver and Slater (1990:21) conceptualise market orientation as having three behavioural dimensions: customer orientation, competitor orientation and interfunctional coordination.

It has been argued that the components of a 'customer' and 'competitor orientation' can be considered to reflect the element of 'information generation' (Diamantopolous \& Hart, 1993: 96). Market orientation as conceptualised by Jaworski and Kohli (1993:54) explicitly includes a broader definition, not limiting the focus to customers but referring to the entire market including competitors, technology and regulations.

Mixed findings in literature are cited for the concepts of 'information dissemination' and 'interfunctional coordination'. Diamantopoulos and Hart (1993:96) suggest that these two dimensions also represent the same element. Narver and Slater's (1990:22) conceptualisation of interfunctional coordination refers to the alignment of functional areas, creating dependencies between departments and sharing of company resources. However, Jaworski and Kohli's (1993:97) concept of 'information dissemination' refers to an effort different departments should make to distribute information either horizontally or vertically in the organisation or via informal or formal channels. The distinction between the two concepts is also supported by Kahn (2001: 
316,319), who found in his research that interdepartmental communication for exchanging information is important. However, active collaboration is more important for achieving performance outcomes. Hence, it is hypothesised that the two concepts 'interfunctional coordination' and 'information dissemination' are distinct and should both be considered in the strategic orientation construct. Even more so, Carrillat et al. (2004:7) emphasise the importance of inter-functional coordination in the process of the organisational change required to achieve market driving.

Based on the discussion, elements of information generation, information dissemination, interfunctional coordination and innovation intensity will be considered. The following alternative hypotheses derive:

$\mathrm{H}_{\mathrm{A}}$ 10: Strategic orientation can be measured by information generation.

$\mathrm{H}_{\mathrm{A}}$ 11: Strategic orientation can be measured by information dissemination.

$\mathrm{H}_{\mathrm{A}} 12$ : Strategic orientation can be measured by interfunctional coordination.

$\mathrm{H}_{\mathrm{A}}$ 13: Strategic orientation can be measured by innovation intensity.

The hypothesis for the structural model is:

$\mathrm{H}_{\mathrm{A}}$ 18: Strategic orientation positively influences market driving ability.

Information generation and information dissemination were measured by four items each, which were taken from the scale developed by Jaworski and Kohli (1993). Interfunctional coordination consisted of four items derived from the scale developed by Narver and Slater (1990). Innovation intensity consisted of three items which were adapted from Miller and Friesen (1982).

\section{Entrepreneurial behaviour}

The last construct on the side of the antecedents of market-driving ability refers to the actions organisations have to take. It has been argued that proactiveness (Morris, 1998:41) and responsiveness to information (Kohli \& Jaworski, 1990:97) both describe an action orientation of the organisation. However, their perspective on the action that should be taken is different and therefore they both make unique contributions to the construct of entrepreneurial behaviour.

Proactiveness has been associated with a forward-looking perspective. Miller and Friesen (1978:923 in Lumpkin \& Dess, 1996:146) consider proactiveness as an action that has to shape the environment by implementing new products, services and technologies. Lumpkin and Dess (1996:146) argue that proactiveness has also been used to describe fast-moving behaviour on the part of the firm, referring to being the quickest to innovate and the first to market. Morris (1998:41) describes proactiveness in a similar way, as an action orientation, referring to Miller's (1987) conception of proactiveness. Miller (1987:10) noted that proactive firms act rather than react to their environments. Morris (1998:41) states that proactiveness is concerned with the implementation of the entrepreneurial concept. Venkatraman (1989:949 in Lumpkin \& Dess, 1996:146) and Morris (1998:41) also describe proactiveness as seeking for new opportunities that may or may not relate to the present line of products and services. A proactive firm is therefore considered to be an initiator rather than a follower of developments.

Responsiveness to market information refers to behaviour that should also be practised by all departments. The response an organisation makes considers the information that has been obtained about the market and the needs expressed. It can take several forms, such as selecting target markets and designing and promoting new products or services (Kohli \& Jaworski, 1990:6; Kohli et al., 1993:468). It is important that market driving organisations develop both sets of skills and know in which situations to apply them (Barlow Hills \& Sarin, 2003:21; Schindehutte et al., 2008:17).

The alternative hypotheses derived are:

$\mathrm{H}_{\mathrm{A}}$ 14: Entrepreneurial behaviour can be measured by proactiveness.

$\mathrm{H}_{\mathrm{A}}$ 15: Entrepreneurial behaviour can be measured by responsiveness to information.

In the structural model it is hypothesised that:

$\mathrm{H}_{\mathrm{A}}$ 19: Entrepreneurial behaviour positively influences market driving ability.

Proactiveness was measured by three items which were adapted from Lumpkin and Dess (2001). The three items used to measure responsiveness to information were adapted from Jaworski and Kohli (1993) and Kohli et al. (1993). 


\section{Firm performance and relative competitive strength}

The market driving literature consistently describes firm performance and competitive advantage to be the outcomes of market driving ability (Carrillat et al., 2004; Kumar et al., 2000; Schindehutte et al., 2008).

In previous entrepreneurship and market orientation research, firm performance was assessed by using financial or non-financial measures (Grinstein, 2008:123; Jaworski \& Kohli, 1993:60; Lumpkin \& Dess, 1996:153155). Moorman and Rust (1999:187) state that most managers are unwilling to disclose objective financial data. Hence, more subjective measures, such as managers' perceptions, are used to assess business performance and are considered to be a reliable indicator, as objective and subjective assessments are strongly correlated.

A comparison of studies that use objective and subjective performance measures shows that these measures are strongly correlated, which demonstrates convergent validity (Dawes, 1999; Dess \& Robinson, 1984; Moorman \& Rust, 1999). Wall et al. (2004:101, 104-111) analysed the validity of subjective measures and included objective and subjective measures. Their study showed convergent and discriminant validity (Wall et al., 2004:101, 104, 111). Considering the results of these studies, subjective measures of financial firm performance provide a reliable measure if objective data cannot be obtained.

To achieve competitive advantage it is necessary to have the required resources, but at the same time to have strategies for transforming these resources into capabilities (Chandler \& Hanks, 1994:335). The conceptual model of market driving ability suggests that, an organisation's market driving ability directly influences a firm's performance and competitive advantage. Market driving ability itself will be positively influenced if the organisation can bring its different resources and strategic orientations together.

Burke (1984:347) developed a measure for relative competitive strength which compared a business unit's position within the market with that of major competitors.

Relative competitive strength was measured by multiple items: product changes, price changes, service improvements, technological innovation and marketing methods. Reliability was assessed by Cronbach's alpha, which was completely satisfactory (alpha $=0.94)$. Discriminant validity between relative competitive strength and other constructs was established (Burke, 1984:351-353).

Augusto and Coelho (2009:96-98,101) state that competitive strength captures aspects of how well a firm can anticipate and shape the market in which it operates. Competitive strength was measured by five items relating to those of the competition: the organisation's prices, quality of products, capacity to compete, diversity of product and its tendency to be ahead of competitors. The items were derived from Burke (1984). Composite reliability, which can be compared to Cronbach's alpha, was acceptable, with a value of 0.81 , which exceeds the reference value of 0.7. Convergent and discriminant validity were established (Augusto \& Coelho, 2009:100).

The market-related and firm-related items considered in different studies provide a good measure of the construct of competitive advantage, as has been demonstrated by the acceptable reliability and validity measures (Augusto \& Coelho, 2009; Burke, 1984; Chandler \& Hanks, 1994; Zhou, Brown \& Dev, 2009).

Firm performance is measured with three self-constructed items and captured respondents' perceptions of firm performance. Relative competitive advantage was measured with five self-constructed items adapted from Burke (1984).

In the structural model, the alternative hypotheses are:

$\mathrm{H}_{\mathrm{A}} 20$ : Market driving ability positively influences firm performance.

$\mathrm{H}_{\mathrm{A}} 21$ : Market driving ability positively influences relative competitive strength.

\section{4}

\section{Methodology}

\subsection{Sample and sampling method}

The study used a non-probability sample using purposive sampling and snowball sampling. From an initial list of contact details of persons obtained from a third party, relevant industries 
and management level were identified. Additionally, screening criteria of minimum turnover and minimum number of employees were introduced to ensure that the firms included represented medium to large-sized enterprises in South Africa. In a second step, a snowball sampling technique was applied. Persons captured in the database were contacted telephonically and asked to refer other colleagues from their organisation or industry. The reason for choosing a nonprobability sampling technique was that respondents in management positions are difficult to identify and contact. In total, 6015 telephonic contacts were made, of which 602 contacts did not meet the screening criteria. Of the remaining 5413 contacts, 962 appointments for telephonic interviews were made, which resulted in 328 realised interviews. The reason for the low number of realised interviews was related to busy work schedules which prevented respondents from participating. The calculated response rate was 34.1 per cent. Consequently non-response error was tested using a comparison between respondents who answered in the early stages of the data collection with those of respondents who participated at later stages (Armstrong \& Overton, 1977:397; Dooley \& Lindner, 2003: 102-103). The hypothesis $\mathrm{H}_{0}$ was tested using SPSS V.9.0 (2004): There is no difference between answers by early versus late respondents with regard to the individual items. The hypothesis was tested using Wilks' lambda (Guthrie, Spell \& Ochoki Nyamori, 2002:190). The analysis showed no difference between early versus late respondents (Wilks' lambda = $0.646, \mathrm{p}>0.10$ ).

\section{Research instrument and data collection}

A statistical modelling approach was followed. The structural model of market driving ability as well as the measurement models for the latent constructs and their dimensions have been discussed. The indicators (items) used were derived from validated measuring instruments previously used in research studies. Furthermore, several self-constructed items, which are based on secondary resources, have been used. Annexure A provides a list of the dimensions and indicators used. In total, 73 items relating to the defined measurement models were asked, using a 5-point Likert-type scale. Respondents were asked to indicate the extent of their agreement with each statement, ranging from $1=$ strongly disagree to $5=$ strongly agree. The items were then used to empirically test the hypotheses outlined in the conceptual model of market driving ability.

\section{Descriptive analysis}

The majority of respondents, 69.5 per cent $(n=228)$, worked for a pharmaceutical manufacturer, 19.2 per cent $(n=63)$ were in the medical device business and 9.2 per cent $(n=30)$ worked for pharmaceutical wholesalers or distributors. Open medical schemes were hardly represented in the sample, with 2.1 per cent $(n=7)$, which can be attributed to the fact that the total number of medical schemes is low and is also constantly decreasing.

20.1 per cent $(n=66)$ respondents were in top management positions in their respective organisations, which included positions like Chief Executive Officer, Chief Financial Officer, Chief Operating Officer or Head of Business Unit. The majority of respondents, 53.1 per cent $(n=174)$, were in middle management positions, which included positions such as Senior Director or Group Leader. Junior management positions included Brand, Financial or Communications Manager and accounted for 26.8 per cent $(n=88)$ of all respondents.

As far as gender was concerned, the sample was almost equally distributed between male 55.5 per cent $(n=182)$ and female 44.5 per cent $(n=146)$ respondents. 60 per cent $(n=196)$ of respondents had more than nine years' experience in the healthcare environment. This gives confidence in the further analysis and demonstrates that respondents know their working environment well.

\section{Reliability and validity of the measuring instrument}

Reliability and validity were assessed as part of the overall statistical model which used partial least squares path modelling (PLS-PM). As the construct of both market driving and the antecedents and consequences of market driving ability have not been assessed empirically before, the exploratory rather than the predictive aspect of this study moves to the fore. Moreover, theory around market driving 
is not well established and therefore empirical data rather than the theory should receive more weight in the analysis. This study used SmartPLS (Ringle, Wende \& Will, 2005) to conduct the required analysis.

The reliability of the reflective concepts was assessed by composite reliability and outer standardised loadings. The outer standardised loadings determine the correlation between the indicator and the latent variable that it is supposed to measure, which should be higher than 0.7 (Henseler, Ringle \& Sinkovics, 2009:299). However, Chin (1998:325) notes that outer loadings with 0.5 and 0.6 can also be considered if research development is in its early stages. Therefore a cut-off criterion of 0.5 was considered. The loadings of the reflective first-order constructs showed that 10 items out of 62 measurement items had to be removed, as they did not meet the cut-off criterion of 0.5 . Although proactiveness showed low loadings for two out of three indicators, one indicator with low loadings was retained, since latent variables with only one indicator cannot determine measurement error (Fornell, 1983:445). The table with original indicator loadings can be obtained from the authors upon request.

Validity of reflective concepts and constructs was determined by convergent validity in the form of the average variance extracted (AVE) and discriminant validity in the form of the cross-loadings. The following table provides the AVE values, showing low values for human capital (0.4781) and entrepreneurial capital (0.2666). Examining the cross-loadings matrix showed that no cross-loadings were identified, which indicates discriminant validity of the reflective concepts (Henseler et al., 2009:300).

Content validity and indicator specification are used to assess the validity of formative constructs (Diamantopoulos \& Winkelhofer, 2001:271). Both indicators can be considered good, as the research instrument was discussed in depth with four industry experts, who confirmed that the necessary constructs had been captured and instructions, content, wording and timing were sound. Multicollinearity was determined by the variance inflation factor (VIF) with values higher than 10 indicating collinearity (Henseler et al., 2009:302). VIF was assessed for the formative constructs and values below 2.9 were achieved for all constructs, which suggests that multicollinearity is not a problem in this study.

External validity assessment followed the suggestions outlined by Diamantopolous and Winkelhofer (2001:272). Correlation analysis between the formative constructs and a global item, summarising the main aspects of the construct, showed significant correlations for all formative constructs. Nomological validity was established by relating each construct to the outcomes parameters of the model, firm performance and relative competitive strength. The results show that all formative constructs are significantly related to the two outcomes parameters, which demonstrates nomological validity.

\section{5}

\section{Results}

To analyse the measurement and structural models SmartPLS (Ringle et al., 2005) was used. The following standard settings of the programme were applied: means $=0$ and variance $=1$. This missing value algorithm was set to mean replacement.

In order to account for variance in the measurement model and the structural model, the following procedures were applied. In the measurement model disturbance terms of second-order formative constructs were set to zero, since PLS assumes that the latent variable is a linear function of its predictor and that there are no linear relationships between the predictors and the residual (Chin \& Newsted, 1999:322; Diamantopoulos et al., 2008:1215). Measurement error is accounted for in reflective first-order indicators. Squared loadings give an indication of how much variance of the observed variable is related to the component. Hence calculating one minus the squared loading gives the amount of variance due to measurement error (Falk \& Miller, 1992:64; Götz, Liehr-Gobbers \& Krafft, 2010:694). In the structural model the variance unaccounted for by the exogenous latent variable is measured by calculating one minus $\mathrm{R}^{2}$ (Falk \& Miller, 1992:72).

To test for significance, the bootstrapping technique was applied with resamples of 
$\mathrm{n}=500$, which follows Henseler and Chin's (2010:95) approach for resampling a parameter using a single sample. Two-tailed tests were performed for the loadings of the reflective constructs and path coefficients in the measurement model. One-tailed tests were performed for the path coefficients in the structural model, since a positive influence had been hypothesised.

\section{Measurement model of market driving}

After all indicators with low loadings had been removed, the market driving measurement model was calculated, resulting in satisfactory convergent validity with AVE values higher than 0.5 (Henseler et al., 2009:299). Annexure $B$ provides a consolidated overview of all constructs, AVE values and composite reliability. Composite reliability for the three first-order reflective concepts, alliance formation (0.8350), market sensing (0.8608) and customer preferences $(0.8345)$ was acceptable, which means that the indicators measured the latent variable well (Henseler et al., 2009:299).

The next step in data analysis deals with the level and significance of path coefficients (Hair, Ringle \& Sarstedt, 2011:147). The path coefficients determine the contribution each concept makes to form the index and represent indicator relevance of the formative concepts (Götz et al., 2010:698; Henseler et al., 2009: 301). Path values can range from -1 to 1 , whereby values of one indicate a perfect positive correlation which would indicate that the same concept is measured twice (Lehner \& Haas, 2010:82). Lohmöller (1989:60) restricts the path model and considers paths from 0.1 as significant. However, Falk and Miller (1992: 77) argue that, given the theoretical formulation of the model, all paths should be reported and their contribution towards the overall model should be presented. This study reports all paths, their magnitude and significance.

The path coefficients for alliance formation (0.259), market sensing (0.552) and influencing customer preferences $(0.413)$ were all positive and significant and hence they contribute to the explanation of market driving, with market sensing and influencing customer preferences contributing to a higher than alliance formation. Therefore hypothesis $\mathrm{H}_{0} 1$ to $\mathrm{H}_{0} 3$ can be rejected.

\section{Measurement model for corporate entrepreneurial management}

Corporate entrepreneurial management $(\mathrm{CE})$ is a second-order formative, first-order reflective construct which was measured by risk-taking (RISK), management support (MGT) and organisational structure (STRU). Risk-taking (RISK) consisted of two variables that showed satisfactory loadings (0.9282 and 0.7575). Management support (MGT) was designed as a concept including four variables that also showed satisfactory loadings $(0.8134,0.8723$, $0.8725,0.8955)$. Organisational structure (STRU) considered four variables, two of which showed low loadings $(0.1536 ;-0.3989)$. These two variables were therefore removed from further analysis.

After recalculating the measurement model with the retained variables, AVE was at a satisfactory level with values above 0.73 . Composite reliability was very satisfactory with values at 0.844 and higher.

The path coefficients for risk-taking ($0.441)$ and organisational structure (0.588) explained corporate entrepreneurial management well and were significant at the 0.01 level and 0.05 level respectively. The path for management support was lower (0.327) and not significant. As corporate entrepreneurial management was measured as a formative construct, the concepts could have either a positive or a negative relationship with the construct (Diamantopoulos et al., 2008:1205). Therefore hypotheses $\mathrm{H}_{0} 4$ and $\mathrm{H}_{0} 6$ can be rejected. However, $\mathrm{H}_{0} 5$ cannot be rejected.

\section{Entrepreneurial capital}

Entrepreneurial capital (CA) was designed as a second-order reflective, first-order reflective construct. The first-order concepts were financial capital (FIN), human capital (HUM) and social capital (SOC).

Financial capital consisted of three measurement items. Owing to low loadings of one item $(-0.3941)$ it was removed from further analysis. Human capital and social capital were measured using three variables each. All variables could be retained for further analysis, since the loadings were acceptable $(>0.60)$.

The measurement model was recalculated with the retained variables. (AVE) for the financial capital $(0.7144)$ and the social capital 
(0.5334) concept was higher than 0.5. Human capital (0.4781) and the overall construct entrepreneurial capital (0.2666) showed lower levels of AVE, which indicated a lack of convergent validity (Hair et al., 2011:146). Composite reliability for all reflective concepts: financial capital (0.833), human capital (0.7321), and social capital $(0.7730)$, and the overall construct entrepreneurial capital $(0.7404)$ were acceptable, which indicated that the variables adequately represented the latent variable.

Considering the path coefficients that reflect the latent variable, it can be noted that all paths were significant at the 0.01 level. Financial capital (0.604), human capital (0.706) and social capital $(0.757)$ were all well reflected by their latent variable. Therefore $\mathrm{H}_{0} 7$ to $\mathrm{H}_{0} 9$ can be rejected.

\section{Measurement model for strategic orientation}

Strategic orientation (SO) was designed as a second-order formative, first-order reflective construct. The reflective concepts included information generation (GEN), information dissemination (DIS), interfunctional coordination (COO) and innovation intensity (INN).

Information generation (GEN) was designed with four items. However, one item had to be deleted owing to low outer loading (0.1428). Information dissemination (DIS) consisted of four items, one of which also had to be removed owing to low outer loading (0.1895).

Interfunctional coordination (COO) included four items, all of which showed high loadings $(>0.69)$. Innovation intensity (INN) was based on three items, one of which had to be removed owing to low loading (-0.1256).

After recalculation, AVE values were satisfactory, with values between 0.5878 and 0.7922 . Composite reliability was very satisfactory, with values of 0.8100 and higher. The path coefficients for information generation, information dissemination and innovation intensity were positive and significant. Interfunctional coordination showed a positive but nonsignificant path. Although interfunctional coordination was not significant, it was retained for further analysis, since the removal of a concept in formative measurement could alter the nature of the overall construct (Diamantopoulos et al., 2008:1205).
The highest contribution to the explanation of strategic orientation was made by information dissemination (0.426), followed by information generation (0.327) and innovation intensity (0.251). The lowest contribution was made by interfunctional coordination (0.229). Therefore $\mathrm{H}_{0} 10, \mathrm{H}_{0} 11, \mathrm{H}_{0} 13$ can be rejected. However, $\mathrm{H}_{0} 12$ cannot be rejected.

\section{Measurement model for entrepreneurial behaviour}

Entrepreneurial behaviour (BE) is a secondorder formative, first-order reflective construct consisting of proactiveness (PRO) and responsiveness to information (RESP).

Proactiveness (PRO) consisted of three items. One item showed low loading (0.0081) and one item demonstrated a negative loading (0.3959 ). In order to obtain internally consistent scales, it would be necessary to remove both items from the scale (Spector, 1992:29). The negative sign of the variable was also reflected in the concept's composite reliability, which was very low (0.0806). However, since a latent variable that is constituted by only one variable cannot account for measurement error (Fornell, 1983:445), the indicator with the negative loading was retained for further analysis, since it showed the higher loading of the two variables.

Responsiveness to information (RESP) was measured with three variables which all showed acceptable outer loadings $(>0.60)$. After recalculation, AVE values were satisfactory, composite reliability was acceptable for responsiveness to information. However pro-activeness could not be shown to be a unidimensional concept.

The path coefficients for the two concepts were significant at the 0.01 level. The highest contribution to the explanation of entrepreneurial behaviour was made by proactiveness (0.595), followed by responsiveness to information (0.557). Therefore $\mathrm{H}_{0} 14$ and $\mathrm{H}_{0} 15$ can be rejected.

\section{Measurement model for firm performance and relative competitive strength}

The measurement model for firm performance (PERF) and relative competitive strength (COMP) was established as a part of the structural model. 
Firm performance (PERF) was originally measured with three variables. However, one item showed low loading (0.4629) and was deleted.

Relative competitive advantage (COMP) was measured with five variables. All variables showed high loadings $(>0.7479)$ and were therefore retained for further analysis.

After recalculation AVE showed a satisfactory level for both reflective concepts with values of 0.7687 for firm performance and 0.6349 for relative competitive strength. Composite reliability was very satisfactory, with values of 0.8690 for firm performance and 0.8966 for relative competitive strength.

The path coefficients for firm performance and relative competitive strength were analysed in the structural model, as they were considered as endogenous concepts in the model.

\section{Structural model}

Once the measurement models had been analysed, the structural model that considered the relationships between latent variables could be considered.

It was hypothesised that direct positive relationships exist (H16-H19) between the exogenous variables and market driving ability. Furthermore, market driving ability was hypothesised to positively influence firm performance and relative competitive strength (H20-H21).

The two primary evaluation criteria for the structural model are the coefficient of determination $\left(\mathrm{R}^{2}\right)$ and the magnitude, sign and significance of the path coefficients (Hair et al., 2011:147). $\mathrm{R}^{2}$ for the endogenous latent variable market driving ability was 0.612 , which indicated almost substantial explanatory power according to the values described by Chin (1998:328).

All path coefficients showed significant results under a one-tailed test via bootstrapping. Strategic orientation (SO) and entrepreneurial behaviour (BE) positively influence market driving ability substantially, while entrepreneurial capital (CA) has a weaker influence. Therefore $\mathrm{H}_{0} 17$ to $\mathrm{H}_{0} 19$ can be rejected. Corporate entrepreneurial management (CE) has a slightly negative impact on market driving ability and $\mathrm{H}_{0} 16$ cannot thus be rejected.
Although the contribution of entrepreneurial capital (CA) and corporate entrepreneurial management (CE) was not high but was significant, both constructs were retained for the structural analysis, for two reasons. First, the constructs present distinct causes of market driving ability, and deleting a construct because of its negative or low impact would potentially alter its nature (Bollen \& Lennox, 1991:308; Diamantopoulos et al., 2008:1205). Second, as indicated by Chin (1995:4), PLS tends to overestimate loadings and underestimate the structural paths. Hence, the structural paths might be even higher if the number of indicators and sample size increased indefinitely.

The path coefficients for market driving ability towards firm performance (0.293) and for relative competitive strength $(0.314)$ are positive and significant, which leads to the rejection of $\mathrm{H}_{0} 20$ and $\mathrm{H}_{0} 21$. Market driving ability positively influences the two specified outcomes parameters.

Figure 2 summarises the path coefficients and $\mathrm{R}^{2}$ for the direct effects model.

A further evaluation criterion for structural models is the effect size $\left(\mathrm{f}^{2}\right)$, which determines the impact of the exogenous latent variable on the endogenous latent variable (Henseler et al., 2009:303). According to Henseler and Chin (2010:105), values of 0.02 indicate a small effect size. Values of 0.15 indicate a medium effect size and values of 0.35 indicate a large effect size.

Effect size for strategic orientation was the largest, at 0.358 , followed by a medium effect size for entrepreneurial behaviour (0.115) and a small effect size for entrepreneurial capital (0.037). The lowest impact on the structural model was made by corporate entrepreneurial management (0.007). Considering these results it can be deduced that organisations that want to increase their market driving ability should start analysing their strategic orientation, followed by entrepreneurial behaviour, as these two constructs demonstrate the highest impact.

To measure the predictive quality of the model, the Stone-Geisser's $\mathrm{Q}^{2}$ can be applied (Hair et al., 2011:147). As $\mathrm{Q}^{2}$ can be applied only to endogenous reflective construct's predictive quality for firm performance and 
relative competitive strength can be assessed. Predictive quality for firm performance was 0.0641 and for relative competitive strength 0.0623 . As both values were larger than zero, it can be deduced that market driving ability exhibits predictive relevance on firm performance and relative competitive strength (Hair et al., 2011:147). $Q^{2}$ measures of 0.02 indicate small predictive relevance; values at 0.15 indicate medium relevance and values at 0.35 show significant predictive relevance (Henseler et al., 2009:305).

Figure 2

Direct effects model

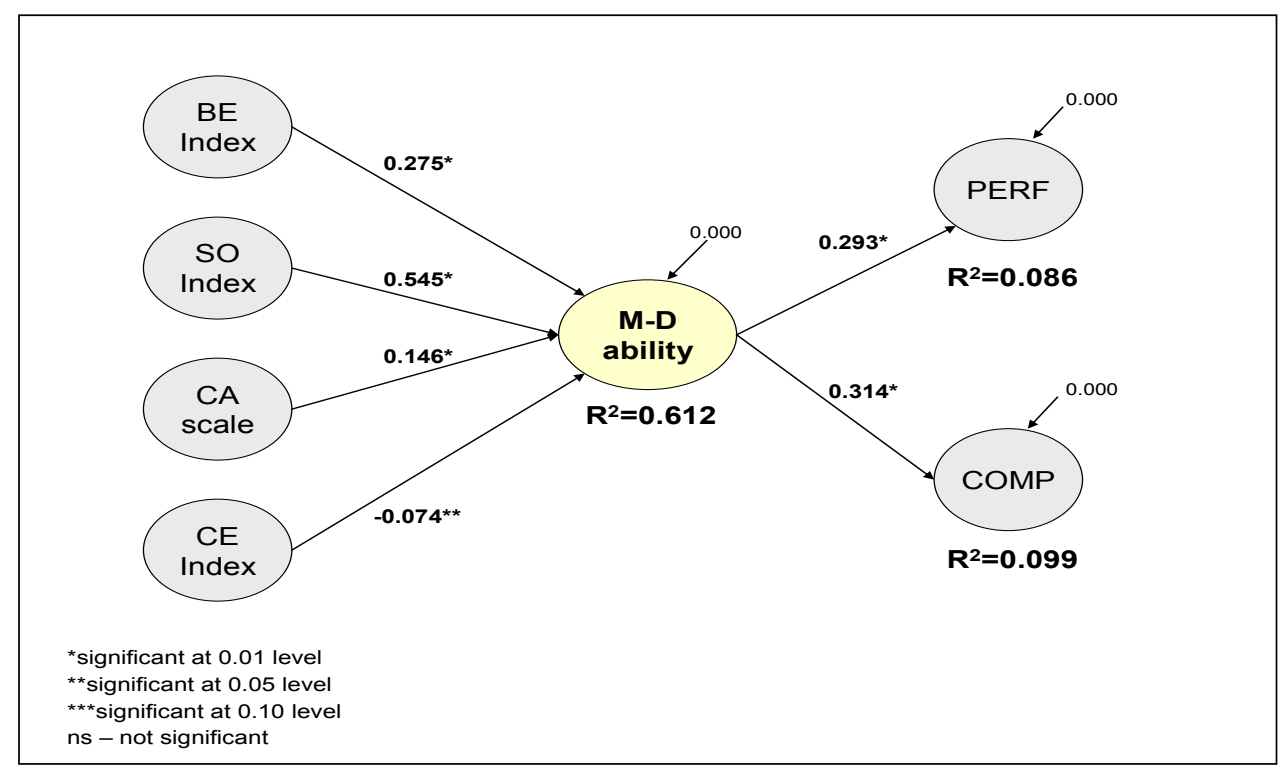

Source: Authors' own compilation

6

\section{Discussion}

The literature discussing market driving argued that certain activities, such as market sensing, shaping customer preferences and alliance formation characterise the construct (Barlow Hills \& Sarin, 2001, 2003; Ghauri, Tarnovskaya \& Elg, 2008; Harris \& Cai, 2002; Jaworski et al., 2000). The results of this study have provided support for these claims.

Market sensing has been described as an important activity for market driving firms to learn about opportunities and how the market reacts to strategic moves (Harris \& Cai, 2002: 185). The results of this study showed that market sensing activities contribute positively to the market driving construct.

Influencing and educating customers about new products and hence trying to change behaviour has been found to be another important aspect of market driving in the literature
(Barlow Hills \& Sarin, 2003; Harris \& Cai, 2002; Jaworski et al., 2000; Kumar et al., 2000). The study also found support for a positive contribution of influencing customer preferences in forming the market driving construct.

The last concept considered in the measurement of market driving was alliance formation. Ghauri et al. (2008) argue that strong relationships with various stakeholders, such as suppliers, retailers or government authorities, are characteristic of market driving firms. The study could support these claims, as alliance formation was shown to positively influence market driving.

Overall, the study showed that market driving can be measured by market sensing, influencing customer preferences and alliance formation. Although the measures of market driving represent only a selection of activities, the results provide a reliable basis for future research on the measurement of market driving. 


\section{Antecedents to market driving ability}

As entrepreneurship and marketing both have significant ownership in market driving research, the literature review outlined a number of firm internal factors that could influence an organisations' market driving ability. The study could partially support findings in the literature.

The first construct, corporate entrepreneurial management included the concepts of risk-taking, management support and organisational structure. While management support and organisational structure positively contribute to the construct, risk-taking was found to negatively influence corporate entrepreneurial management. Regarding the overall impact of corporate entrepreneurial management on market driving ability, it was somewhat surprisingly found that the construct impacted market driving ability slightly negatively and hence is not an enabling factor. A possible explanation for this could be found in the external environment of organisations considered in this research. Schindehutte et al. (2008:13) consider an environmental aspect in their model, stating that market forces, uncertainty and competitive intensity impact on a firm's ability to compete and hence their market driving. As the South African healthcare industry is preparing for the implementation of National Health Insurance (NHI), which will change the current industry set-up, it might be likely that this factor has implicitly impacted the study. Furthermore, during the period of this research, government published its plan for the implementation of NHI and an international consulting workshop was initiated.

In the literature study, it was suggested that market driving ability also requires entrepreneurial capital to be present (Ghauri et al., 2008; Schindehutte et al., 2008). Entrepreneurial capital was represented in the form of financial, human and social capital in the study, which showed that all three types of resources reflect well the construct of entrepreneurial capital. In accordance with the literature, the study found that entrepreneurial capital positively impacts on market driving ability.

A strategic orientation is considered to be important for market driving activities. Barlow
Hills and Sarin (2001:219) state that a strategic orientation is formed by certain capabilities, such as an understanding of customers and competitors and networking capability. Furthermore, the necessary presence of innovation in an organisation has been emphasised (Jaworski et al., 2000; Kumar et al., 2000; Schindehutte et al., 2008). The research study considered aspects of information generation, dissemination, interfunctional coordination and innovation intensity in the construct of strategic orientation. The results provided support for the positive and significant influence of these factors in measuring the strategic orientation of the organisation. The study also provided support for a positive influence of strategic orientation on market driving ability.

Entrepreneurial behaviour reflected in seeing opportunities and filling unmet needs in the market is considered to enable market driving ability (Kumar et al., 2000). The research study included the specific behaviours of proactiveness and responsiveness to information. The results showed that both concepts represent the entrepreneurial behaviour construct well. It could also be demonstrated that entrepreneurial behaviour positively influences market driving ability.

The outcomes of a market driving approach have been described as impacting on firm performance and competitive advantage (Carrillat et al., 2004; Harris \& Cai, 2002; Schindehutte et al., 2008). The results of this study support the findings described in the literature. Market driving ability positively influences firm performance and relative competitive strength.

The limitations of this study should be addressed in future research. However, considering that this study made a first attempt to measure market driving in South Africa, reliable and valid results could be obtained which could guide further research. The limitations include the non-probability sample which limits the generalisation of results. Further, the study was cross-sectional. In addition, the number of concepts used to measure market driving and firm internal factors were limited and should be extended for future research. The same applies to the external factors that could be considered. 
7

\section{Conclusion and recommendations}

There is consensus that, in today's environment, organisations should apply a holistic view to the entire business and its stakeholders and apply a different mind-set to achieve outstanding business performance.

One construct that has been linked to exceptional performance and competitive advantage is a firm's ability to achieve market driving (Kumar et al., 2000; Schindehutte et al., 2008).

The study addressed previous researchers' recommendations to determine how market driving could be measured (Barlow Hills \& Sarin, 2003:21; Carrillat et al., 2004:10; Jaworski et al., 2000:53). The study showed that a reliable and valid assessment of market driving could be achieved with three concepts, addressing market sensing, influencing customer preferences and organisational alliance-formation activities. Furthermore, previous researchers have outlined the importance of understanding which organisational factors facilitate or hinder an organisation in becoming market driving and go towards understanding the outcomes of market driving (Barlow Hills \& Sarin, 2003: 21; Schindehutte et al., 2008:22).

In this study, a conceptual framework was provided that considers several firm internal factors: corporate entrepreneurial management, entrepreneurial capital, strategic orientation and entrepreneurial behaviour, as well as two outcomes parameters, firm performance and relative competitive strength. It was hypothesised that the firm internal factors will positively influence organisations' market driving ability. The model was operationalized using reliable and valid items from previous studies, as well as self-constructed items based on secondary sources. It was empirically tested in the South African healthcare industry. The realised sample of $n=328$ included respondents from pharmaceutical manufacturers $(n=228)$, medical device manufacturers $(n=63)$; pharmaceutical distributors/wholesalers $(n=30)$ and open medical schemes $(n=7)$.

The model was analysed using SmartPLS (Ringle et al., 2005). Tests for reliability and validity of indicators, concepts and the construct were conducted and provided satisfactory results. The overall model demonstrated explanatory power with $\mathrm{R}^{2}$ of 0.612 . The path coefficients were significant for all firm internal latent variables. Strategic orientation (SO) and entrepreneurial behaviour (BE) influence market driving ability substantially, while entrepreneurial capital (CA) has a weaker influence. Corporate entrepreneurial management (CE) has a slightly negative impact on market--driving ability. The analysis also showed that market driving influences firms' performance and relative competitive strength positively and significantly. Overall, the study contributes to the body of knowledge in the field of market driving research. The study has integrated constructs of entrepreneurial and market orientation, supporting previous researchers' view that both disciplines need to be considered in today's competitive market environment (Kumar et al., 2000; Schindehutte et al., 2008; Schindehutte et al., 2009:29). For researchers and practitioners alike, this study demonstrates that an analysis of firm internal factors can help understand from where an organisation's strength can be derived. This should then be the point of departure for shaping, changing or creating new markets or customer segments.

\section{Acknowledgement}

The authors would like to thank the reviewers of this article for their contribution.

\section{References}

ANTONCIC, B. \& HISRICH, R.D. 2001. Intrapreneurship: construct refinement and cross-cultural validation. Journal of Business Venturing, 16(5):495-527.

ARMSTRONG, J.S. \& OVERTON, T.S. 1977. Estimating nonresponse bias in mail surveys. Journal of Marketing Research, 14(3):396-402.

ATUAHENE-GIMA, K. \& KO, A. 2001. An empirical investigation of the effect of market orientation and entrepreneurship orientation alignment on product innovation. Organization Science, 12(1):54-74. 
AUGUSTO, M. \& COELHO, F. 2009. Market orientation and new-to-the-world products: exploring the moderating effects of innovativeness, competitive strength, and environmental forces. Industrial Marketing Management, 38(1):94-108.

BARLOW HILLS, S. \& SARIN, S. 2001. Understanding market driving capability in high-technology industries: a theoretical framework for examining firm strategic orientation and strategy selection. Paper presented at the American Marketing Association Conference Proceedings, Winter, (12):217-222.

BARLOW HILLS, S. \& SARIN, S. 2003. From market driven to market driving: an alternate paradigm for marketing in high technology industries. Journal of Marketing Theory and Practice, 11(3):13-24.

BARNEY, J. 1991. Firm resources and sustained competitive advantage. Journal of Management, 17(1):99-120. BARON, R.A. \& MARKMAN, G.D. 2000. Beyond social capital: how social skills can enhance entrepreneurs' success. Academy of Management Executive, 14(1):106-118.

BARRINGER, B.R. \& BLUEDORN, A.C. 1999. The relationship between corporate entrepreneurship and strategic management. Strategic Management Journal, 20(5):421-444.

BOLLEN, K. \& LENNOX, R. 1991. Conventional wisdom on measurement: a structural equation perspective. Psychological Bulletin, 110(2):305-314.

BROWN, T., DAVIDSSON, P. \& WIKLUND, J. 2001. An operationalization of Stevenson's conceptualization of entrepreneurship as opportunity-based firm behaviour. Strategic Management Journal, 22(10):953-968.

BRUSH, C.G., GREENE, P.G. \& HART, M.M. 2001. From initial idea to unique advantage: The entrepreneurial challenge of constructing a resource base. Academy of Management Executive, 15(1):64-80. BURKE JARVIS, C., MACKENZIE, S.B. \& PODSAKOFF, P.M. 2003. A critical review of construct indicators and measurement model misspecification in marketing and consumer research. Journal of Consumer Research, 30(2):199-218.

BURKE, M.C. 1984. Strategic choice and marketing managers: an examination of business-level marketing objectives. Journal of Marketing Research, 21(4):345-359.

CADOGAN, J.W., SOUCHON, A.L. \& PROCTER, D.B. 2008. The quality of market-oriented behaviours: formative index construction. Journal of Business Research, 61(12):1263-1277.

CARSON, D. 2010. Interface research: a commentary on a commentary - ten years on. Journal of Research in Marketing and Entrepreneurship, 12(1):8-10.

CARRILLAT, F.A., JARAMILLO, F. \& LOCANDER, W.B. 2004. Market driving organizations: a framework. Academy of Marketing Science Review, 8(6). Available at: http://www.amsreview.org/articles/ carrillat052004.pdf [accessed: 2009-09-19].

CHADWICK, K., BARNETT, T. \& DWYER, S. 2008. An empirical analysis of the entrepreneurial orientation scale. Journal of Applied Management and Entrepreneurship, 13(4):64-84.

CHANDLER, G.N. \& HANKS, S.H. 1994. Market attractiveness, resource-based capabilities, venture strategies, and venture performance. Journal of Business Venturing, 9(4):331-349.

CHIN, W.W. 1995. Partial least squares is to Lisrel as principal components analysis is to common factor analysis. Available at: http://disc-nt.cba.uh.edu/chin/technologystudies.pdf [accessed 2011-02-23].

CHIN, W.W. 1998. The partial least squares approach to structural equation modelling. In: Marcoulides, G.A. (ed.) Modern methods for business research. Mahwah: Lawrence Erlbaum Associates.

CHIN, W.W. \& NEWSTED, P.R. 1999. Structural equation modelling analysis with small samples using partial least squares. In: Hoyle, R.H. (ed.) Statistical strategies for small sample research, Thousand Oaks, CA: Sage.

COVIN, J.G. \& MILES, M.P. 1999. Corporate entrepreneurship and the pursuit of competitive advantage. Entrepreneurship Theory and Practice, 24(3):47-63.

COVIN, J.G. \& SLEVIN, D.P. 1991. A conceptual model of entrepreneurship as firm behaviour. Entrepreneurship Theory and Practice, 16(1):7-25.

DAWES, J. 1999. The relationship between subjective and objective company performance measures in market orientation research: further empirical evidence. Marketing Bulletin, 10 (Research note 3). Available at: http://marketing-bulletin.massey.ac.nz/V10/MB_V10_N3_Dawes.pdf [accessed 2011-01-08].

DAY, G.S. 1998. What does it mean to be market driven? Business Strategy Review, 9(1):1-14.

DE CAROLIS, D.M., LITZKY, B.E. \& EDDLESTON, K.A. 2009. Why networks enhance the progress of new venture creation: the influence of social capital and cognition. Entrepreneurship Theory and Practice, 33(2):527-545. 
DEEDS, D.L. \& HILL, C.W.L. 1996. Strategic alliances and the rate of new product development: an empirical study of entrepreneurial biotechnology firms. Journal of Business Venturing, 11(1):41-55.

DESS, G.G. \& ROBINSON, R.B. 1984. Measuring organizational performance in the absence of objective measures: the case of the privately-held firm and conglomerate business unit. Strategic Management Journal, 5(3):265-273.

DESS, G.G., LUMPKIN, G.T. \& MCGEE, J.E. 1999. Linking corporate entrepreneurship to strategy, structure, and process: suggested research directions. Entrepreneurship Theory and Practice, 24(3):85-102. DESS, G.G., IRELAND, R.D., ZAHRA, S.A., FLOYD, S.W., JANNEY, J.J. \& LANE, P.J. 2003. Emerging issues in corporate entrepreneurship. Journal of Management, 29(3):351-378.

DIAMANTOPOULOS, A. \& HART, S. 1993. Linking market orientation and company performance: preliminary evidence on Kohli and Jaworski's framework. Journal of Strategic Marketing, 1(2):93-121.

DIAMANTOPOULOS, A. \& WINKELHOFER, H.M. 2001. Index construction with formative indicators: an alternative to scale development. Journal of Marketing Research, 38(2):269-277.

DIAMANTOPOULOS, A., RIEFLER, P. \& ROTH, K.P. 2008. Advancing formative measurement models. Journal of Business Research, 61(12):1203-1218.

DICKSON, P.H. \& WEAVER, K.M. 1997. Environmental determinants and individual-level moderators of alliance use. Academy of Management Journal, 40(2):404-425.

DOOLEY, L.M. \& LINDNER, J.R. 2003. The handling of nonresponse error. Human Resource Development Quarterly, 14(1):99-110.

EDWARDS, J.R. 2001. Multidimensional constructs in organizational behaviour research: an integrative analytical framework. Organizational Research Methods, 4(2):144-192.

FALK, R.F. \& MILLER, N.B. 1992. A primer for soft modeling. Akron: University of Akron Press. FORNELL, C. 1983. Issues and application of covariance structure analysis: a comment. Journal of Consumer Research, 9(4):443-448.

GEORGE, B.A. 2011. Entrepreneurial orientation: a theoretical and empirical examination of the consequences of differing construct representations. Journal of Management Studies (forthcoming) accepted article. Available at: doi.10.1111/j.1467-6486.2010.01004.x [accessed 2011-04-03].

GHAURI, P.N., TARNOVSKAYA, V. \& ELG, U. 2008. Market driving multinationals and their global sourcing network. International Marketing Review, 25(5):504-519.

GÖTZ, O., LIEHR-GOBBERS, K. \& KRAFFT, M. 2010. Evaluation of structural equation models using the partial least squares (PLS) approach. In: Esposito Vinzi, V., Chin, W.W., Henseler, J. \& Wang, H. (eds.) Handbook of partial least squares: concepts, methods and applications. Heidelberg: Springer.

GREEN, K.M., COVIN, J.G. \& SLEVIN, D.P. 2008. Exploring the relationship between strategic reactiveness and entrepreneurial orientation: the role of structure-style fit. Journal of Business Venturing, 23(3):356-383.

GRINSTEIN, A. 2008. The relationship between market orientation and alternative strategic orientations. European Journal of Marketing, 42(1/2):115-134.

GULATI, R. 1999. Network location and learning: the influence of network resources and firm capabilities on alliance formation. Strategic Management Journal, 20(5):397-420.

GUTH, W.D. \& GINSBERG, A. 1990. Guest editors' introduction: corporate entrepreneurship. Strategic Management Journal, 11 (special issue):5-15.

GUTHRIE, J.P., SPELL, C.S. \& OCHOKI NYAMORI, R. 2002. Correlates and consequences of high involvement work practices: the role of competitive strategy. International Journal of Human Resource Management, 13(1):183-197.

HAIR, J.F., RINGLE, C.M. \& SARSTEDT, M. 2011. PLS-SEM: indeed a silver bullet. Journal of Marketing Theory and Practice, 19(2):139-151.

HARMSEN, H. \& JENSEN, B. 2004. Identifying the determinants of value creation in the market: a competence-based approach. Journal of Business Research, 57(5):533-547.

HARRIS, L.C. \& CAI, K.Y. 2002. Exploring market driving: a case study of De Beers in China. Journal of Market-Focused Management, 5(3):171-196.

HENSELER, J. \& CHIN, W.W. 2010. A comparison of approaches for the analysis of interaction effects between latent variables using partial least squares path modeling. Structural Equation Modeling, 17(1):82-109. 
HENSELER, J., RINGLE, C.M. \& SINKOVICS, R.R. 2009. The use of partial least squares path modelling in international marketing. Advances in International Marketing, 20(4):277-319.

HISRICH, R.D. \& PETERS, M.P. 1986. Establishing a new business venture unit within a firm. Journal of Business Venturing, 1(3):307-322.

HITT, M.A. \& IRELAND, R.D. 2002. The essence of strategic leadership: managing human and social capital. Journal of Leadership and Organizational Studies, 9(1):3-14.

HITT, M.A., BIERMAN, L., SHIMIZU, K. \& KOCHHAR, R. 2001. Direct and moderating effects of human capital on strategy and performance in professional service firms: a resource-based perspective. Academy of Management Journal, 44(1):13-28.

HITT, M.A., DACIN, M.T., LEVITAS, E., ARREGLE, J.-L. \& BORZA, A. 2000. Partner selection in emerging and developed market contexts: resource-based and organizational learning perspectives. Academy of Management Journal, 43(3):449-467.

HOLT, D.T., RUTHERFORD, M.W. \& CLOHESSY, G.R. 2007. Corporate entrepreneurship: an empirical look at individual characteristics, context, and process. Journal of Leadership and Organizational Studies, 13(4):40-54.

HORNSBY, J.S., KURATKO, D.F. \& MONTAGNO, R.V. 1999. Perception of internal factors for corporate entrepreneurship: a comparison of Canadian and US managers. Entrepreneurship Theory and Practice, 24(2):9-24.

HORNSBY, J.S., KURATKO, D.F. \& ZAHRA, S.A. 2002. Middle managers' perception of the internal environment for corporate entrepreneurship: assessing a measurement scale. Journal of Business Venturing, 17(3):253-273.

HORNSBY, J.S., NAFFZIGER, D.W., KURATKO, D.F. \& MONTAGNO, R.V. 1993. An interactive model of corporate entrepreneurship process. Entrepreneurship Theory and Practice, 18(2):29-37.

HUNT, S. \& MORGAN, R. 1996. The Resource-Advantage Theory of Competition: Dynamics, Path Dependencies, and Evolutionary Dimensions. Journal of Marketing, 60(4):107-114.

IRELAND, R.D., HITT, M.A. \& VAIDYANATH, D. 2002. Alliance management as a source of competitive advantage. Journal of Management, 28(3):413-446.

JACCARD, J. \& JACOBY, J. 2010. Theory construction and model-building skills. New York: Guilford Press. JAWORSKI, B., KOHLI, A.K. \& SAHAY, A. 2000. Market driven versus driving markets. Journal of the Academy of Marketing Science, 28(1):45-54.

JAWORSKI, B.J. \& KOHLI, A.K. 1993. Market orientation: antecedents and consequences. Journal of Marketing, 57(3):53-70.

KAHN, K.B., 2001. Market orientation, interdepartmental integration, and product development performance. Journal of Product Innovation Management 18(X):314-323.

KALE, P., SINGH, H. \& PERLMUTTER, H. 2000. Learning and protection of proprietary assets in strategic alliances: building relational capital. Strategic Management Journal, 21(3):217-237.

KHANDWALLA, P.N. 1977. The design of organizations. New York: Harcourt Brace Jovanovich. KHANDWALLA, P.N. 1987. Generators of pioneering-innovative management: some Indian evidence. Organization Studies, 8(1):39-59.

KIM, W.C. \& MAUBORGNE R. 2005. Value innovation: a leap into the blue ocean. Journal of Business Strategy, 26(4):22-28.

KIRCA, A.H., JAYACHANDRAN, S. \& BEARDEN, W.O. 2005. Market orientation: a meta-analytic review and assessment of its antecedents and impact on performance. Journal of Marketing, 69(2):24-41. KOHLI, A.K. \& JAWORSKI, B.J. 1990. Market orientation: the construct, research propositions, and managerial implications. Journal of Marketing, 54(2):1-18.

KOHLI, A.K., JAWORSKI, B.J. \& KUMAR, A. 1993. MARKOR: a measure of market orientation. Journal of Marketing Research, 30(4):467-477.

KREISER, P.M., MARINO, L.D. \& WEAVER, K.M. 2002. Assessing the psychometric properties of the entrepreneurial orientation scale: a multi-country analysis. Entrepreneurship Theory and Practice, 26(4):71-94.

KUMAR, N., SCHEER, L. \& KOTLER, P. 2000. From market driven to market driving. European Management Journal, 18(2):129-142. 
KURATKO, D.F., IRELAND, R.D. \& HORNSBY, J.S. 2001. Improving firm performance through entrepreneurial actions: Acorida's corporate entrepreneurship strategy. Academy of Management Executive, 15(4):60-71.

KURATKO, D.F., MONTAGNO, R.V. \& HORNSBY, J.S. 1990. Developing an intrapreneurial assessment instrument for an effective corporate entrepreneurial environment. Strategic Management Journal, 11 (special issue summer):49-58.

KURATKO, D.F., HORNSBY, J.S., NAFFZIGER, D.W. \& MONTAGNO, R.V. 1993. Implement entrepreneurial thinking in established organizations. SAM Advanced Management Journal, 58(1):28-39.

LAW, K.S. \& WONG, C.-S. 1999. Multidimensional constructs in structural equation analysis: an illustration using the job perception and job satisfaction constructs. Journal of Management, 25(2):143-160.

LAW, K.S., WONG, C.-S. \& MOBLEY, W.H. 1998. Toward a taxonomy of multidimensional constructs. Academy of Management Review, 23(4):741-755.

LEHNER, F. \& HAAS, N. 2010. Knowledge management success factors - proposal of an empirical research. Electronic Journal of Knowledge Management, 8(1):79-90.

LOHMÖLLER, J.-B. 1989. Latent variable path modeling with partial least squares. Heidelberg: PhysicaVerlag.

LUMPKIN, G.T. \& DESS, G.G. 1996. Clarifying the entrepreneurial orientation construct and linking it to performance. Academy of Management Review, 21(1):135-172.

LUMPKIN, G.T. \& DESS, G.G. 2001. Linking two dimensions of entrepreneurial orientation to firm performance: the moderating role of environment and industry life cycle. Journal of Business Venturing, 16(5):429-451.

MACCALLUM, R.C. \& BROWNE, M.W. 1993. The use of causal indicators in covariance structure models: some practical issues. Psychological Bulletin, 114(3):533-541.

MACKENZIE, S.B., PODSAKOFF, P.M. \& BURKE JARVIS, C. 2005. The problem of measurement model misspecification in behavioural and organizational research and some recommended solutions. Journal of Applied Psychology, 90(4):710-730.

MATSUNO, K., MENTZER, J.T. \& ÖZSOMER, A. 2002. The effects of entrepreneurial proclivity and market orientation on business performance. Journal of Marketing, 66(3):18-32.

MILES, M.P. \& ARNOLD, D.R. 1991. The relationship between marketing orientation and entrepreneurial orientation. Entrepreneurship Theory and Practice, 15(4):49-65.

MILLER, D. \& FRIESEN, P.H. 1982. Innovation in conservative and entrepreneurial firms: two models of strategic momentum. Strategic Management Journal, 3(1):1-25.

MILLER, D. 1983. The correlates of entrepreneurship in three types of firms. Management Science, 29(7):770-791.

MILLER, D. 1987. Strategy making and structure: analysis and implications for performance. Academy of Management Journal, 30(1):7-32.

MOORMAN, C. \& RUST, R.T. 1999. The role of marketing. Journal of Marketing, 63(special issue):180-197. MORGAN, R.E. \& STRONG, C.A. 2003. Business performance and dimensions of strategic orientation. Journal of Business Research, 56(3):163-176.

MORRIS, M.H. \& SEXTON, D.L. 1996. The concept of entrepreneurial intensity: implications for company performance. Journal of Business Research, 36(1):5-13.

MORRIS, M.H. 1998. Entrepreneurial intensity: sustainable advantages for individuals, organizations, and societies. Westport, CT: Quorum.

NARVER, J.C. \& SLATER, S.F. 1990. The effect of a market orientation on business profitability. Journal of Marketing, 54(4):20-35.

NARVER, J.C., SLATER, S.F. \& MACLACHLAN, D. 2004. Responsive and proactive market orientation and new-product success. Journal of Product Innovation Management, 21(5):334-347.

PEARL, J. 2007. Causality: models, reasoning and inference. New York: Cambridge University Press.

RAUCH, A., FRESE, M. \& UTSCH, A. 2005. Effects of human capital and long-term human resources development and utilization on employment growth of small-scale businesses: a causal analysis.

Entrepreneurship Theory and Practice, 29(6):681-698 
RAUCH, A., WIKLUND, J., LUMPKIN, G.T \& FRESE, M. 2009. Entrepreneurial orientation and business performance: an assessment of past research and suggestions for the future. Entrepreneurship Theory and Practice, 33(3):761 (27p). [Online] Available at: Academic OneFile. http://0-find.galegroup.com [accessed 2009-07-27].

RINGLE, C., WENDE, S. \& WILL, A. 2005. SmartPLS 2.0 (beta). Universität Hamburg. Available at: www.smartpls.de [accessed 2011-03-16].

ROSSITER, J.R. 2002. The C-OAR-SE procedure for scale development in marketing. International Journal of Research in Marketing, 19(4):305-335.

ROTHAERMEL, F.T. \& DEEDS, D.L. 2006. Alliance type, alliance experience and alliance management capability in high-technology ventures. Journal of Business Venturing, 21(4):429-460.

SCHINDEHUTTE, M., MORRIS, M.H. \& KOCAK, A. 2008. Understanding market driving behaviour: the role of entrepreneurship. Journal of Small Business Management, 46(1):4-26.

SCHINDEHUTTE, M., MORRIS, M.H. \& PITT, L.F. 2009. Rethinking marketing: the entrepreneurial imperative. New Jersey: Pearson Prentice Hall.

SHMUELI, G., 2010. To explain or to predict? Statistical Science, 25(3):289-310.

SLATER, S.F. \& NARVER, J.C. 1998. Customer-led and market-oriented: let's not confuse the two. Strategic Management Journal, 19(10):1001-1006.

SMART, D.T. \& CONANT, J.S. 1994. Entrepreneurial orientation, distinctive marketing competencies and organizational performance. Journal of Applied Business Research, 10(3): 28p. [Online] Available at: EBSCOHost: Business Source Premier: http://0-search.ebsohost.com.innopac.up.ac.za [accessed 2010-08-05].

SPECTOR, P.E. 1992. Summated rating scale construction: an introduction. Newbury Park: Sage University Papers.

SPSS Inc. 2004. SPSS V. 9.0. Chicago, Illinois.

TENG, B.S. \& CUMMINGS, J.L. 2002. Trade-offs in managing resources and capabilities. Academy of Management Executive, 16(2):81-91.

TUOMINEN, M., RAJALA, A. \& MÖLLER, K. 2004. Market driving versus market driven: divergent roles of market orientation in business relationships. Industrial Marketing Management, 33(3):207-217.

UNGER, J.M., RAUCH, A., FRESE, M. \& ROSENBUSCH, N. 2011. Human capital and entrepreneurial success: a meta-analytical review. Journal of Business Venturing 26(3):341-358.

VENKATRAMAN, N. 1989. Strategic orientation of business enterprises: The construct, dimensionality and measurement. Management Science, 35(8):942-962.

WALL, T.D., MiCHIE, J., PATTERSON, M., WOOD, S.J., SHEHAN, M., CLEGG, C.W. \& WEST, M. 2004. On the validity of subjective measures of company performance. Personnel Psychology, 57(1):95-118.

ZAHRA, S.A. 1991. Predictors and financial outcomes of corporate entrepreneurship: an exploratory study. Journal of Business Venturing, 6(4):259-285.

ZHOU, K.Z., BROWN, J.R. \& DEV, C.S. 2009. Market orientation, competitive advantage, and performance: A demand-based perspective. Journal of Business Research, 62(11):1063-1070.

Annexure A

\begin{tabular}{|l|}
\hline Item \\
\begin{tabular}{|l|l|}
\hline Firm Performance: Comparing your firm's performance for 2008 and 2009 please rate \\
\hline Q1A & $\ldots$ the overall level of financial performance, e.g. company profit, net financial results \\
\hline Q1B & $\ldots$ the overall level of market share in $\%$ \\
\hline Q1C & $\ldots$ the overall development of cost base, e.g. production cost, operating expense \\
\hline Relative competitive strength: Relative to your major competitor please rate \\
\hline Q66 & $\ldots$ how well your products/services meet client's needs \\
\hline Q67 & $\ldots$ the quality of handling client requests and queries \\
\hline Q68 & $\ldots$ your firm's image \\
\hline Q69 & $\ldots$ your firm's ability to gain market share \\
\hline Q70 & $\ldots$ your firm's ability to transfer knowledge efficiently within the firm \\
\hline
\end{tabular}
\end{tabular}




\begin{tabular}{|c|c|}
\hline \multicolumn{2}{|c|}{ Organisational structure: At our firm } \\
\hline Q1 & ... we have a flat organisational structure \\
\hline Q2 & ... we have many standard procedures that everyone must follow \\
\hline Q3 & ... we have open channels of communication \\
\hline Q4 & ... employees are free to take decisions within their scope of responsibilities \\
\hline \multicolumn{2}{|c|}{ Management support } \\
\hline Q5 & Upper Management is aware and very receptive to employees' ideas and suggestions \\
\hline Q6 & $\begin{array}{l}\text { Those employees who come up with innovative ideas on their own often receive management encouragement for } \\
\text { their activities }\end{array}$ \\
\hline Q7 & An employee with a good idea is often given free time to develop that idea \\
\hline Q8 & Management provides a conducive environment for staff to communicate and understand each other \\
\hline \multicolumn{2}{|c|}{ Risk taking } \\
\hline Q9 & We have a strong inclination / tendency to low risk projects, with normal and certain rates of return \\
\hline Q10 & We would never pursue any projects that could potentially result in any kind of loss \\
\hline \multicolumn{2}{|c|}{ Proactiveness } \\
\hline Q11 & We try to anticipate developments in the market in order to adjust to changes quickly \\
\hline Q12 & In dealing with our competitors we typically respond to actions which competitors initiate \\
\hline Q13 & Compared to our competitors we are very seldom the first business to introduce new products or services \\
\hline \multicolumn{2}{|c|}{ Responsiveness to the market } \\
\hline Q14 & Usually we implement changes suggested by business partners \\
\hline Q15 & We regularly analyse our relationships with business partners and respond quickly to major issues \\
\hline Q16 & If we identify gaps in our product/service delivery we respond by taking appropriate actions \\
\hline \multicolumn{2}{|c|}{ Information generation } \\
\hline Q17 & We regularly meet with clients to learn how to serve them better \\
\hline Q18 & We are slow to detect changes in our clients' product or service preferences \\
\hline Q19 & Our firm does a lot of market research \\
\hline Q20 & We spend a lot of time discussing clients' future needs with business partners \\
\hline \multicolumn{2}{|c|}{ Information dissemination } \\
\hline Q21 & Management regularly communicates industry developments to staff \\
\hline Q22 & We have regular meetings to discuss market trends and developments \\
\hline Q23 & When one department finds out something important about competitors, it is slow to alert other departments \\
\hline Q24 & $\begin{array}{l}\text { Our firm regularly circulates reports or newsletters internally that provide information on our clients, competitors or } \\
\text { the industry }\end{array}$ \\
\hline \multicolumn{2}{|c|}{ Interdepartmental coordination } \\
\hline Q25 & Information that is received from e.g. sales consultants is distributed within all relevant departments \\
\hline Q26 & We share a lot of business information with different departments \\
\hline Q27 & All departments work together in offering value to the client \\
\hline Q28 & Different departments share resources, for example business systems with each other \\
\hline \multicolumn{2}{|c|}{ Innovation intensity } \\
\hline Q29 & We have a strong emphasis on research and development of new products/services \\
\hline Q30 & In the past 5 years our firm has marketed plenty new products/services \\
\hline Q31 & Changes in product or service offerings have been mostly of minor nature \\
\hline \multicolumn{2}{|c|}{ Financial capital } \\
\hline Q35 & If we want to pursue an opportunity in the market we will make the financial means available \\
\hline Q36 & There is a tight control on financial resources that are spent on product or service development \\
\hline Q37 & There is always enough funding for marketing our products and services to the public \\
\hline \multicolumn{2}{|c|}{ Social capital } \\
\hline Q38 & I feel comfortable working with people from diverse backgrounds \\
\hline Q39 & I have strong connections to various different business networks \\
\hline Q40 & I spend a significant amount of my time discussing business with external network partners \\
\hline
\end{tabular}




\begin{tabular}{|c|c|}
\hline \multicolumn{2}{|c|}{ Human capital } \\
\hline Q41 & For middle and higher management positions our firm would only consider candidates with university degrees \\
\hline Q42 & Our middle and higher management consists of people from various knowledge backgrounds \\
\hline Q43 & For middle and higher management positions our firm would only consider candidates with management experience \\
\hline \multicolumn{2}{|c|}{ Influencing customer preferences } \\
\hline Q50 & We continuously monitor clients complaints about products or services that our firm offers \\
\hline Q51 & We change clients preferences by offering products or services that have not been available before \\
\hline Q52 & $\begin{array}{l}\text { We constantly deliver exceptional products or services that outperform the products or services delivered by } \\
\text { competitors }\end{array}$ \\
\hline Q53 & We regularly inform our clients about our developments regarding new products or services, market trends etc \\
\hline \multicolumn{2}{|c|}{ Alliance formation } \\
\hline Q54 & In the past 4 years we have had very few alliances with other firms \\
\hline Q55 & The total number of alliances has increased in the past 4 years \\
\hline Q56 & We have benefited a lot from our current and previous alliances to run our business successfully \\
\hline Q57 & It is difficult to find the right alliance partners as we take a long time to develop mutual trust \\
\hline Q58 & We have a process that allows us to evaluate alliance options and the benefits for our firm \\
\hline \multicolumn{2}{|r|}{$\begin{array}{l}\text { Market sensing: Please rate the extent to which the following scanning devices are used by your firm to gather information } \\
\text { about your business environment }\end{array}$} \\
\hline Q61 & Regular evaluation of opinions from clients \\
\hline Q62 & Explicit tracking of strategies and tactics of competitors \\
\hline Q63 & Forecasting future sales \\
\hline Q64 & Research on future challenges, for example government regulations \\
\hline Q65 & Collecting information from business partners or associations \\
\hline
\end{tabular}

\section{Annexure B}

\begin{tabular}{|c|c|c|c|}
\hline Concept / Indicator & $\begin{array}{l}\text { Outer loading after } \\
\text { recalculation }\end{array}$ & AVE & Composite reliability \\
\hline \multicolumn{4}{|l|}{ Alliance formation } \\
\hline Q55 & $0.7404^{*}$ & \multirow{3}{*}{0.6284} & \multirow{3}{*}{0.8350} \\
\hline Q56 & $0.8199^{*}$ & & \\
\hline Q58 & $0.8152^{*}$ & & \\
\hline \multicolumn{4}{|l|}{ Market sensing } \\
\hline Q61 & $0.7672^{*}$ & \multirow{5}{*}{0.5540} & \multirow{5}{*}{0.8608} \\
\hline Q62 & $0.8002^{*}$ & & \\
\hline Q63 & $0.6608^{*}$ & & \\
\hline Q64 & $0.7116^{*}$ & & \\
\hline Q65 & $0.7733^{*}$ & & \\
\hline \multicolumn{4}{|l|}{ Influencing customer preferences } \\
\hline Q50 & $0.6896^{*}$ & \multirow{4}{*}{0.5587} & \multirow{4}{*}{0.8345} \\
\hline Q51 & $0.7052^{*}$ & & \\
\hline Q52 & $0.7782^{*}$ & & \\
\hline Q53 & $0.8100^{*}$ & & \\
\hline \multicolumn{4}{|l|}{ Risk-taking } \\
\hline Q9 & $0.8527^{*}$ & \multirow{2}{*}{0.7301} & \multirow{2}{*}{0.8440} \\
\hline Q10 & $0.8563^{*}$ & & \\
\hline \multicolumn{4}{|l|}{ Management support } \\
\hline Q5 & $0.8823^{*}$ & \multirow{4}{*}{0.7488} & \multirow{4}{*}{0.9226} \\
\hline Q6 & $0.8899^{*}$ & & \\
\hline Q7 & $0.8360^{*}$ & & \\
\hline Q8 & $0.8521^{*}$ & & \\
\hline
\end{tabular}




\begin{tabular}{|c|c|c|c|}
\hline Organisational structure & & & \\
\hline Q3 & $0.9204^{*}$ & \multirow{2}{*}{0.8309} & \multirow{2}{*}{0.9076} \\
\hline Q4 & $0.9025^{\star}$ & & \\
\hline $\begin{array}{l}\text { Latent variable } \\
\text { Entrepreneurial capital (CA) - reflective }\end{array}$ & - & 0.2666 & 0.7404 \\
\hline \multicolumn{4}{|l|}{ Financial capital } \\
\hline Q35 & $0.8930^{*}$ & \multirow{2}{*}{0.7144} & \multirow{2}{*}{0.8330} \\
\hline Q37 & $0.7964^{*}$ & & \\
\hline \multicolumn{4}{|l|}{ Human capital } \\
\hline Q41 & $0.6138^{*}$ & \multirow{3}{*}{0.4781} & \multirow{3}{*}{0.7321} \\
\hline Q42 & $0.7296^{*}$ & & \\
\hline Q43 & $0.7248^{*}$ & & \\
\hline \multicolumn{4}{|l|}{ Social capital } \\
\hline Q38 & $0.6502^{*}$ & \multirow{3}{*}{0.5334} & \multirow{3}{*}{0.7730} \\
\hline Q39 & $0.7954^{*}$ & & \\
\hline Q40 & $0.7381^{*}$ & & \\
\hline \multicolumn{4}{|l|}{ Information generation } \\
\hline Q17 & $0.7121^{*}$ & \multirow{3}{*}{0.5878} & \multirow{3}{*}{0.8100} \\
\hline Q19 & $0.7600^{*}$ & & \\
\hline Q20 & $0.8239^{*}$ & & \\
\hline \multicolumn{4}{|l|}{ Information dissemination } \\
\hline Q21 & $0.8537^{*}$ & \multirow{3}{*}{0.7087} & \multirow{3}{*}{0.8793} \\
\hline Q22 & $0.8754^{*}$ & & \\
\hline Q24 & $0.7942^{*}$ & & \\
\hline \multicolumn{4}{|l|}{ Interfunctional coordination } \\
\hline Q25 & $0.8048^{*}$ & \multirow{4}{*}{0.6569} & \multirow{4}{*}{0.8840} \\
\hline Q26 & $0.8762^{*}$ & & \\
\hline Q27 & $0.8291^{*}$ & & \\
\hline Q28 & $0.7243^{*}$ & & \\
\hline \multicolumn{4}{|l|}{ Innovation intensity } \\
\hline Q29 & $0.9131^{*}$ & \multirow{2}{*}{0.7922} & \multirow{2}{*}{0.8840} \\
\hline Q30 & $0.8664^{*}$ & & \\
\hline \multicolumn{4}{|l|}{ Proactiveness } \\
\hline Q11 & $0.8865^{\star}$ & 05826 & 00806 \\
\hline Q12 & $-0.6160^{*}$ & $0.50<0$ & 0.0000 \\
\hline Responsiveness to information & & & \\
\hline Q14 & $0.6614^{*}$ & & \\
\hline Q15 & $0.8684^{*}$ & 0.6100 & 0.8225 \\
\hline Q16 & $0.7990^{*}$ & & \\
\hline Firm performance & & & \\
\hline Q1A & $0.8330^{*}$ & 07687 & 08690 \\
\hline Q1B & $0.9185^{\star}$ & 0.1001 & 0.0050 \\
\hline Relative competitive strength & & & \\
\hline Q66 & $0.7471^{*}$ & & \\
\hline Q67 & $0.8043^{*}$ & & \\
\hline Q68 & $0.8522^{*}$ & 0.6349 & 0.8966 \\
\hline Q69 & $0.8233^{*}$ & & \\
\hline Q70 & $0.7520^{*}$ & & \\
\hline
\end{tabular}

Note: * indicates significance at 0.01 level 